\title{
Major Depresif Bozukluk Tanılı 350 Ergen Olgunun Klinik Özellikleri, Hastalık Şiddeti ve Tedavi Seçeneklerinin Değerlendirilmesi: Retrospektif Kesitsel Bir Çalışma
}

\section{Evaluation of Clinical Characteristics, Severity of Disease and Treatment Options in 350 Adolescent Patients with Major Depressive Disorder: A Retrospective Cross-sectional Study}

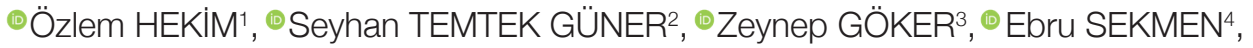

• Özden Şükran ÜNERi ${ }^{5}$

${ }^{1}$ Sağlık Bilimleri Üniversitesi, Ankara Gülhane Eğitim Araștırma Hastanesi, Çocuk ve Ergen Ruh Sağlı̆̆ı ve Hastalıkları Kliniği,

Ankara,Türkiye

${ }^{2}$ Keçiören Eğitim Araştırma Hastanesi, Çocuk ve Ergen Ruh Sağlığı ve Hastalıkları Bölümü, Ankara,Türkiye

${ }^{3}$ Sağlık Bilimleri Üniversitesi, Ankara Çocuk Sağlığı ve Hastalıkları Hematoloji Onkoloji Eğitim Araştırma Hastanesi, Çocuk ve Ergen

Ruh Sağlığı ve Hastalıkları Kliniği, Ankara,Türkiye

${ }^{4}$ Adıyaman Eğitim Araştırma Hastanesi, Çocuk ve Ergen Ruh Sağlı̆̆ı ve Hastalıkları Bölümü, Adıyaman,Türkiye

${ }^{5}$ Ankara Yıldırım Beyazıt Üniversitesi, Tıp Fakültesi, Çocuk ve Ergen Ruh Sağlı̆̆ı ve Hastalıkları Anabilim Dalı, Ankara,Türkiye

\section{ÖZ}

Amaç: Major Depresif Bozukluk (MDB) ergenlik döneminde sık görülen önemli bir ruh sağlığı sorunudur. Çalışmamızda MDB tanısı ile takip ve tedaviye alınan ergenlerde depresyon şiddetinin, kullanılan tedavi yöntemlerinin ve klinik özelliklerin değerlendirilmesi amaçlanmıştır.

Gereç ve Yöntemler: 1 Ocak-31 Aralık 2015 tarihleri arasında hastanemiz çocuk ve ergen psikiyatrisi polikliniğine ayaktan başvuran ve DSM 5'e göre unipolar MDB tanısı konan 12-18 yaş aralığındaki 350 ergen hastanın dosyası geriye dönük olarak incelenmiş ve bu ergenlerin sosyodemografik ve klinik özellikleri değerlendirilmiştir. İstatistiksel değerlendirme için SPSS 17.0 kullanılmıştır.

Bulgular: Bir yıllık zaman diliminde polikliniğe başvuran 4.646 ergenin 350'sine (\% 7.5) MDB tanısı konmuştur. Kız ergenler Örneklemin \%75.4'ünü oluşturmaktaydı. Ergenler depresyon şiddeti açısından sınıflandırıldığında, tüm örneklemin \%45.7'sinin hafif, \%44.3'ünün orta ve \%10'unun ağır şiddetli depresyon grubunda yer aldığı ve tüm bu gruplarda kız ergenlerin daha yüksek oranda olduğu bulunmuştur. Örneklem tedaviler açısından değerlendirildiğinde \%81.7'sine farmakoterapi, \%15.1'ine çeşitli psikoterapiler, \%3.1'ine ise farmakoterapi ve psikoterapi kombinasyonu uygulanmıştır. Ergenlerin \%87.4'ünde seçici serotonin geri alım inhibitörleri (SSGi) tek başına tercih edilmiştir. Somatoform bozukluk (disosiyatif ve konversif bozukluk) ve yas reaksiyonu varlığında hekimlerin farmakoterapi ve psikoterapi kombinasyonunu daha sık tercih ettiği saptanmıştır. Farmakoterapi alan ergenlerin \%.8.6'sında en az bir yan etki varlığı saptanmıştır.

Sonuç: Çalışmamız daha önceki bulgularla uyumlu olarak MDB tanısının kız ergenlerde daha sık olduğunu ve sıklığın hastalığın şiddetinden etkilenmediğini göstermiştir. Ayrıca ülkemizde de bu yaş grubunda MDB için SSGi monoterapisinin çoğu kez ilk seçenek olarak kullanıldığı belirlenmiştir. Çalışmamız ülkemizde MDB tanılı ergenlerde yapılmış geniş örneklemli, tedavi ve şiddet değerlendirmesini içeren nadir çalışmalardan biridir ve bu açıdan alan yazına katkı sağlayacağı düşünülmüştür fakat bu verilerin kesitsel, geriye dönük ve durum saptaması niteliğinde olması nedenleriyle genellenmesi uygun olmayabilir ve uzunlamasına yapılan çalışmalara olan ihtiyaç devam etmektedir.

Anahtar Sözcükler: Ergen, Klinik özellikler, Major depresif bozukluk

\begin{abstract}
Objective: Major Depressive Disorder (MDD) is an important mental health disorder that is common in adolescence. In our study, it was aimed to evaluate depression severity, treatment methods and clinical features of adolescents who were followed up and treated with MDD diagnosis.
\end{abstract}

Material and Methods: Between January and December 2015, 350 adolescent patients between 12-18 years of age who consulted with child and adolescent psychiatry clinic and diagnosed by unipolar MDD according to DSM-5 
was reviewed. The sociodemographic and clinical features of these cases were evaluated. SPSS 17.0 was used for statistical evaluation.

Results: MDD was diagnosed in 350 (7.5\%) of 4.646 adolescents who applied to the outpatient clinic during the 1-year period. Girls were $75.4 \%$ of the sample. When the cases were classified in terms of severity of depression, it was found that $45.7 \%$ of the whole sample was mild, $44.3 \%$ was middle and $10 \%$ was severe MDD and the girls were higher in all groups. Pharmacotherapy was applied in $81.7 \%$ of the sample, $15.1 \%$ of psychotherapies, $3.1 \%$ of the combination of pharmacotherapy and psychotherapy. Selective serotonin reuptake inhibitors (SSRIs) alone were preferred in $87.4 \%$ of the cases. Somatoform disorder (dissociative and conversion disorder) and bereavement reaction were significant for the combined use of pharmacotherapy and psychotherapy. At least one adverse event was detected in $8.8 \%$ of the cases.

Conclusion: Compatibly the literature, in adolescence MDD diagnosis was significantly more common in females in all severity groups. SSRIs monotherapy is mostly used as the first option in treatment. Our study will contribute to the related literature in terms of involving wide sampling, treatment and severity evaluation in adolescents with MDD; but generalization may not be appropriate because of the the study's cross-sectional and situation determination nature.

Key Words: Adolescent, Clinical features, Major depressive disorder

\section{GiRiş}

Major Depresif Bozukluk (MDB) ergenlik döneminde sık görülen, intihar davranışı için yüksek risk oluşturan ve işlevsellikte bozulmaya yol açan önemli bir ruh sağlığı bozukluğudur. DSM-5'e göre MDB tanısı için iki hafta boyunca süren en az beş belirti gerekmektedir. Bu belirtilerden biri ya depresif veya irritabl duygudurum ya da ilgi kaybı ve zevk alamama şeklinde olmalıdır. Diğer belirtiler ise iştah ve/veya uyku değişiklikleri, psikomotor ajitasyon ya da retardasyonun olması, enerji kaybı, değersizlik-suçluluk duyguları, konsantrasyon kaybı, ölüm düşünceleri ya da planlarını kapsamaktadır. Bu belirtiler mutlaka akademik ve/veya sosyal işlevsellikte bozulmaya neden olmalı, bir madde kullanımının ya da genel tıbbi bir durumun doğrudan etkilerine bağı olmamalıdır (1). MDB'nin yaygınlığı ile ilgili yapılan birçok çalışmada MDB'nin çocukluk döneminde \%1-2, ergenlik döneminde ise \%5 oranında olduğu belirtilmektedir (2). Thapar ve ark. (3) alanda yaptıkları sistematik bir derleme çalışmasında depresyonun kümülatif sıklığı, erken ergenlik döneminde yaklaşık \%5 iken ergenliğin sonuna doğru bu oranın \%20'ye yükseldiği bildirilmiştir. MDB'nin etiyolojisinde genetik, biyokimyasal, psikodinamik ve sosyokültürel etkenlerin rolü olduğuna dair fikir birliği vardır (4). Ebeveyn ölümü veya ayrllığı, aile üyelerinde psikiyatrik bir rahatsızlı̆ın olması, istismar ve inmale maruz kalma, ebeveyn desteğine daha fazla gereksinim duyma ve okul başarısızığının ergenlerde depresyon görülme durumu ile yakın ilişkili etkenler olduğu bildirilmektedir (5-8). MDB ergenlik öncesi kIz ve erkek cinsiyette benzer oranlarda görülürken, ergenlikten sonra kızlarda görülme olasilığı erkeklere göre daha yüksektir (9). Ergenlik dönemindeki kızlarda depresyonun görülme sıkı̆̆ının artışında hormonal ve çevresel etkenlerin rol oynadığı düşünülmektedir (10). Ancak bu etkenlerin daha iyi anlaşılabilmesi için yeni çalışmalara gereksinim vardır. Ergenlik döneminde MDB klinik özellikleri erişkin döneme benzerlikler gösterse de sigara/alkol/madde kullanımı, okuldan ve evden kaçma, akademik başarıda düşme, öfke nöbetleri gibi riskli davranışlar ergenlik dönemi MDB'de daha sık görülmektedir. MDB'nin seyri değişkendir. Çocuk ve ergenlerde klinik ve toplum örnekleminde major depresif dönem ortancaları sırası ile 8 ay ve 1-2 ay olarak bildirilmiştir (11). Çalışmalar çocuk ve ergenlerin çoğunun ilk MDB dönemi sonrası iyileştiğini ancak yineleme oranlarının yüksek olduğu ve ergenlerin bir kısmında kronikleşme olabileceğini düșündürmektedir. Yineleme oranları düzelme sonrası ilk 2 yll için \%20-60, 5 yll içerisinde ise \%70 olarak bildirilmiştir $(3,12,13)$.

İlgili yazın incelendiğinde çocuk ve ergen yaş grubunda MDB şiddetinin değerlendirildiği az sayıda çalıșma olduğu görülmektedir. Ergen yaş grubunda Dünya Sağlık Örgütü'nün DSM IV'e göre Kompozit Uluslararası Teșhis GörüşmesiSürüm 3.0 (World Health Organization Composite International Diagnostic Interview Version 3.0 (CIDI)) uygulanarak yapılıış bir çalışmada, rahatsızlık ve bozulma kriterleri CIDl' nin her bir tanı bölümüne dahil edilmiştir. Buna göre MDB dahil olmak üzere tüm DSM-IV tanıları, var olan rahatsızlığın düzeyine göre "orta", "ağır", "çok ağır" veya var olan bozukluğun derecesine göre "biraz" "çok", "aşırı" olarak sınıflandırılmıştır (14).

Ergenlerde MDB'ye eşlik eden ruhsal bozukluklar açısından alan yazın değerlendirildiğinde MDB tanısı alan ergenlerin \%4090'nına en az bir ruhsal bozukluğun, yaklașık \%50'sine ise iki veya daha fazla ruhsal bozukluğun eşlik ettiği saptanmıştır. Çalıșmalarda MDB ile birlikte en sık görülen bozukluklar, kaygı bozuklukları (çocuklarda ayrlık kaygısı bozukluğu, ergenlerde sosyal fobi ve yaygın anksiyete bozukluğu öncelikli olmak üzere), distimik bozukluk, DEHB, karşıt olma- karşı gelme bozukluğu, davranım bozukluğu, alkol ve madde kötüye kullanımı olarak bildirilmiştir (15-16). MDB tanılı ergenlerin \%35-50 sinin en az bir kez intihar girişiminde bulunduğu ve ilgili çalsşmalarda intihar girişimi veya gerçekleşmiş intihar olasılığının yaşla birlikte arttığı belirtilmiştir $(17,18)$.

MDB tedavisinde etkinliği kontrollü araştırmalarla gösterilmiş çok sayıda yöntem bulunmaktadır. Psikososyal terapiler ve farmakoterapi tedavi seçenekleri arasındadır. Tedavide seçilecek yöntem hastanın yaşı, bilişsel gelişimi, belirtilerin şiddeti, eş tanıların varlığı, eșlik eden diğer tıbbi durumlar, aile öyküsü, sosyal çevre gibi çok sayıda değişken göz önünde bulundurularak seçilmelidir. MDB tanısı alan tüm ergenlerde, psikoeğitim tedavinin ilk basamağını oluşturmaktadır. Diğer destekleyici psikoterapiler arasında kişiler arası terapi (KAP), bilişsel davranışçı terapi (BDT) ve ailenin tedaviye katılımı 
olarak özetlenebilir. Genel olarak hafif şiddette MDB'si olan ergenlerde psikososyal çevre düzenlemeleri ve destekleyici psikoterapi yeterli olabilmektedir (19). Önemli derecede işlevsellik kaybı, aktif intihar düşüncesi ve davranışları olan ya da psikotik belirtileri olan, orta ağır şiddette depresyon ya da tekrarlayıcı MDB atakları olan ergenlerde en uygun tedavi BDT ve farmakoterapinin birlikte uygulanmasıdır (20).

Günümüzde MDB, çocuk ve ergenlerde giderek artan oranlarda gözlenen önemli bir ruh sağlığı problemidir. Gelișim basamaklarını henüz tamamlamamış olan çocuk ve ergenler için, MDB tedavi edilmediği takdirde bireyin bilişsel, sosyal ve psikolojik gelişimini olumsuz etkilemektedir. Dünya Sağllk Örgütü, MDB tanılı bireylerde ortaya çıkan yeti kaybının diğer kronik hastalı̆ı olan bireylerde gözlenen yeti kaybından daha yüksek oranlarda olduğunu bildirmiştir (21). Bu açıdan bakıldığında MDB'nin tanınması ve tedavi edilmesi son derece önemlidir. Ülkemizde ergenlik çağında MDB ile ilgili yapılan çalışmaların nitelik ve nicelik açısından sınırı sayıda oldukları gözlenmektedir. Çalışmamızda çocuk psikiyatrisi kliniğine başvuran ve MDB tanısı ile takip ve tedaviye alınan ergenlerin sosyodemografik ve klinik özellikleri ile uygulanan tedavi seçeneklerinin değerlendirilmesi amaçlanmıştır.

\section{GEREÇ ve YÖNTEMLER}

Çalışma için Ankara Çocuk Sağlığı ve Hastalıkları Hematoloji Onkoloji Eğitim ve Araştırma Hastanesi Etik Kurul Komitesinden etik kurul onayı alınmıştır. Ocak-Aralık 2015 tarihleri arasında çocuk ve ergen psikiyatrisi polikliniğine ayaktan başvuran ergen (12-18 yaş) hastaların dosyaları geriye dönük olarak incelenmiştir. DSM 4 TR tanı kriterlerine göre MDB tanıSı alan ergenlerin dosyaları seçilerek sosyodemografik ve klinik özellikleri değerlendirilmiştir. Çalışmamızda, depresyon şiddeti, IACAPAP (The International Association for Child and Adolescent Psychiatry and Allied Professions)'In önerisi ile klinik bulgu sayısına göre belirlenmiş olup belirtilerden en az biri çekirdek belirti olmak üzere beș depresif belirti ve işlevsellikte hafif bozulma 'hafif düzey MDB', altı veya yedi depresif belirti ve okul, iş hayatında anlamlı zorluklar yaşama 'orta düzey MDB', yediden fazla depresif belirti, psikotik belirti veya intihar riski varlığı ve işlevsellikte anlamlı bozulma olma durumu ise 'ağır düzey MDB' olarak sınıflandırımıştır (2). Hastalara uygulanan tedavi yötemlerine göre ise hastalar 3 gruba ayrımıştır: 1 . psikoterapötik girişimler (kısa psikososyal yaklaşım, bilişsel yapılandırmaya yönelik motivasyonel görüşmeler, destekleyici görüşmeler, psikoeğitim, aile eğitimi), 2. farmakoterapi ve 3. BDT-farmakoterapi kombinasyonu

İstatistiksel Analiz: Normal dağllıma uygunluk analizi için Kruskal-Wallis testi, kategorik değişkenlerin analizi için kikare ve Fisher's exact testi, sürekli değişkenlerin analizi için ise ANOVA testi kullanılmıştır. Kategorik değişkenler sıkık (n) ve yüzde (\%) olarak, sürekli değişkenler aritmetik ortalama ve standart sapma değerleri şeklinde ifade edilmiştir. $p<0.05$ değeri istatistiksel olarak anlamlı kabul edilmiştir. İstatistiksel analizlerde SPSS 17.0 programı kullanılmıştır.

\section{BULGULAR}

Bir ylllık zaman diliminde, 12-18 yaş aralığında, çocuk psikiyatrisi polikliniğimize başvuran ergen sayısı 4.646'dır. Örneklemimizi oluşturan MDB tanıı ergen sayısı 350 (\%7.5), yaş ortalaması $15.9( \pm 1.5)$ yll olarak belirlenmiştir. Çalışmaya alınan ergenlerin \%76'sına ( $n=266$ ) bir yillık kesitte ilk kez MDB tanısı konulmuştur. Kız ergenler örneklemin \%75.4'ünü ( $n=264)$ oluşturmuştur.

Örneklem depresyon şiddeti açısından gruplara ayrılarak değerlendirildiğinde tüm örneklemin \%45.7'sinin ( $n=160)$ hafif şiddetli depresyon, \%44.3'ünün ( $n=155$ ) orta şiddetli depresyon ve \%10'unun ( $n=35)$ ağır şiddetli depresyon grubunda yer aldığı bulunmuştur. Depresyon şiddetine göre belirlenen gruplar arasında yaş ortalaması açısından istatistiksel olarak anlamlı fark olmadı̆̆ı saptanmıştır ( $F=0.181, p=0.835)$. Tüm gruplarda kız ergenlerin sayıca anlamlı olarak daha yüksek oranda olduğu görülmüştür $(\chi 2(2)=13.431, p=0.001)$. Depresyon şiddeti açısından ilk defa tanı alan ergenler ile takipte olan ergenlerin dağılım oranlarının benzer olduğu saptanmıştır (Pearson $\chi 2(2)=$ 3.621, $p=0.164$ ).

Örneklemde toplam 230 ergenin ailede kaçıncı çocuk olduğu bilgisine ulaşılmıştır. Buna göre 137 ergenin ailede ilk ve 55 ergenin ailede ikinci çocuk olduğu görülmüştür (\%39.1 (n=137) birinci çocuk, \%15.7 ( $n=55)$ ikinci çocuk). Gruplar arasında depresyon şiddeti ile ailede kaçıncı çocuk olduğu değişkeni arasında anlamlı bir ilişki saptanmamıştır (Pearson $\chi 2(8)=$ 6.119, $p=0.624$ ).

Örneklemde toplam 319 ergenin yapısal aile özelliklerine (çekirdek aile, geniş aile) ulaşılmıştır. Buna göre örneklemin \%73.4'ünün ( $n=234)$ çekirdek ailede yaşadığı görülmüş ve gruplar arasında depresyon şiddeti ile aile yapısı açısından istatistiksel anlamlı bir ilişkinin olmadığı saptanmıştır (Pearson $\chi^{2}(8)=5.363, p=0.672$, Fisher's exact test).

Toplam 348 ergenin okula devamllık durumuna ait bilgilere ulaşılmış olup bunların \%94.5'inin ( $n=329)$ örgün eğitime, \%1.4'ünün ( $n=5)$ açık eğitime devam ettiği, yalnızca \%4'ünün $(n=14)$ herhangi bir eğitime devam etmediği öğrenilmiştir. Depresyon şiddeti ile ergenlerin okula devamlilığı arasında istatiksel bir anlamllık saptanmamışıı $(\chi 2(4)=6.724, p=0.106$, Fisher's exact test).

Örneklemde toplam 287 ergenin aile öyküsüne ulaşılmış ve birinci derece yakınlarında bir psikiyatrik bozukluk tanısı olup olmadığı değerlendirilmiştir. Buna göre ergenlerin \%33.8'inin $(n=97)$ birinci derece yakınında en az bir psikiyatrik bozukluk tanı varığı bulunmuştur. Aile öyküsünde psikiyatrik bozukluk tanı varlığı ile MDB tanısı alan ergenler arasında istatiksel olarak anlamlı bir ilişki olduğu saptanmıştır (Non-parametrik-tek grup- 
Tablo I: Depresyon şiddetine göre demografik ve klinik özelliklerin analizi

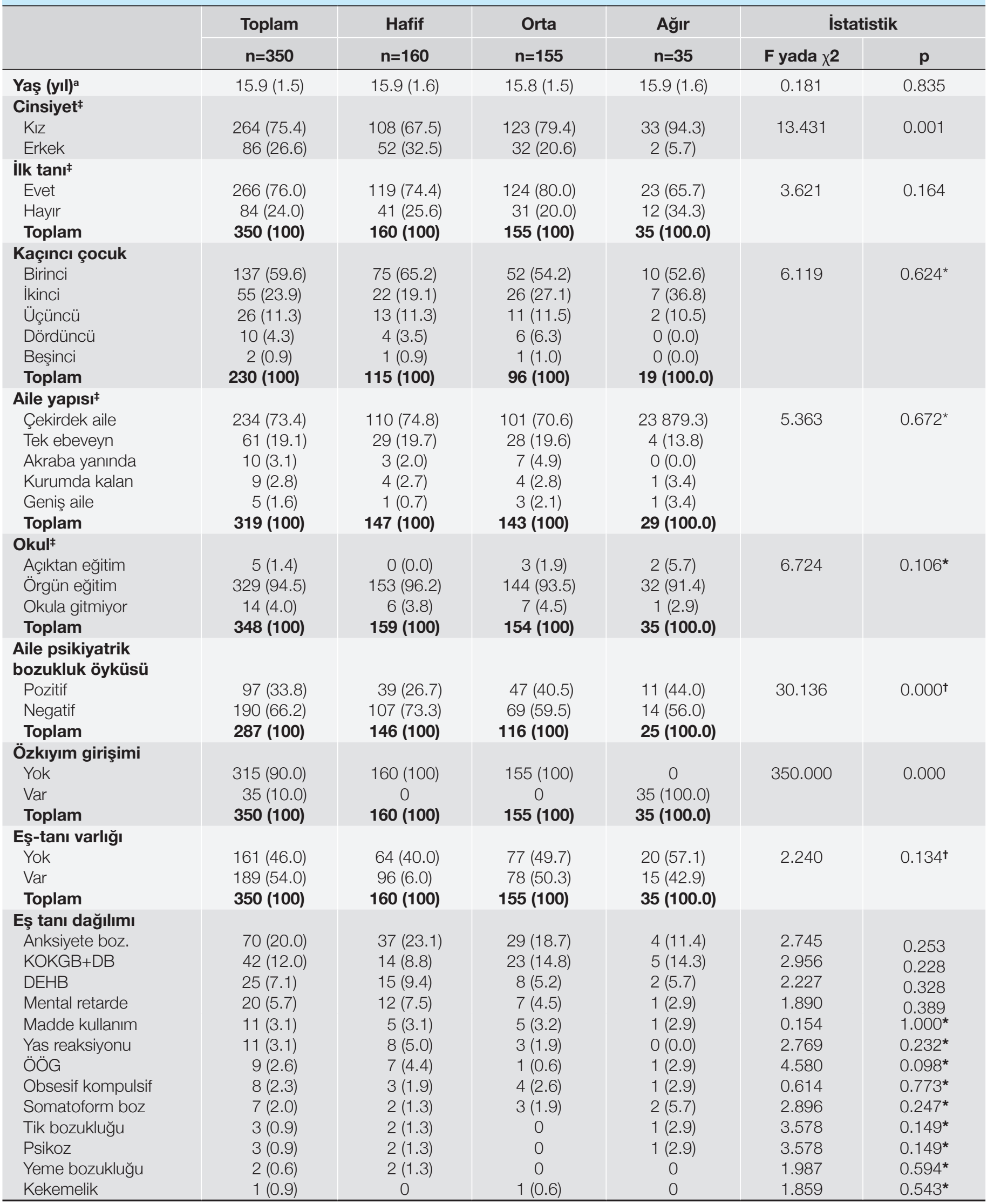

a: Ortalama (Standart sapma), *: Fisher's exact test, 't: Non-parametrik tek grup ki-kare testi, KOKGB: Karşı olma karşı gelme bozukluğu, DB: Davranım bozukluğu, DEHB: Dikkat eksikliği hiperaktivite bozukluğu, ÖöG: Özgül öğrenme güçlüğü, *:n(\%). 
Tablo II: Uygulanan tedavi protokollerinin depresyon șiddetine göre dağlımları.

\begin{tabular}{|c|c|c|c|c|c|c|}
\hline & \multirow{2}{*}{$\begin{array}{c}\text { Toplam } \\
\mathrm{n}=350\end{array}$} & \multirow{2}{*}{$\begin{array}{c}\text { Hafif } \\
n=160\end{array}$} & \multirow{2}{*}{$\begin{array}{c}\text { Orta } \\
n=155\end{array}$} & \multirow{2}{*}{$\begin{array}{l}\text { Ağır } \\
\mathrm{n}=35\end{array}$} & \multicolumn{2}{|c|}{ İstatistik } \\
\hline & & & & & $x^{2}$ & p değeri \\
\hline $\begin{array}{l}\text { Tedavi }^{\dagger} \\
\text { Ilaç tedavisi } \\
\text { Psikoterapi } \\
\text { Ilaç + BDT } \\
\text { Toplam }\end{array}$ & $\begin{array}{c}286(81.7) \\
53(15.1) \\
11(3.1) \\
\mathbf{3 5 0}(\mathbf{1 0 0 . 0 )}\end{array}$ & $\begin{array}{c}119(74.4) \\
40(25.0) \\
1(0.6) \\
160(\mathbf{1 0 0 . 0 )}\end{array}$ & $\begin{array}{c}135(87.1) \\
12(7.7) \\
8(5.2) \\
155(\mathbf{1 0 0 . 0 )}\end{array}$ & $\begin{array}{c}32 \text { (91.4) } \\
1(2.9) \\
2(5.7) \\
\mathbf{3 5}(\mathbf{1 0 0 . 0 )}\end{array}$ & 27.936 & 0.000 \\
\hline $\begin{array}{l}\text { İlaçlar }{ }^{\dagger} \\
\text { Yok } \\
\text { SSGI } \\
\text { SNGI } \\
\text { NEGI } \\
\text { Atipik Antipsikotik } \\
\text { SSGI+AA } \\
\text { SSGl+NaSSA } \\
\text { SNGI+AA }\end{array}$ & $\begin{array}{c}10(2.9) \\
306(87.4) \\
2(0.6) \\
2(0.6) \\
5(1.4) \\
21(6.0) \\
2(0.6) \\
1(0.3)\end{array}$ & $\begin{array}{c}3(1.9) \\
142(88.8) \\
0 \\
2(1.3) \\
3(1.9) \\
8(5.0) \\
1(0.6) \\
0\end{array}$ & $\begin{array}{c}7(4.5) \\
139(89.7) \\
2(1.3) \\
0(0.0) \\
2(1.3) \\
3(1.9) \\
1(0.6) \\
1(0.6)\end{array}$ & $\begin{array}{c}0 \\
25(71.4) \\
0 \\
0 \\
0 \\
10(28.6) \\
0 \\
0\end{array}$ & 33.746 & $0.000^{*}$ \\
\hline
\end{tabular}

BDT: Bilişsel Davranış̧̧ı Terapi, SSRI: Selektif Serotonin Gerialım Inhibitörleri (fluoksetin, sertralin, essitalopram, sitalopram), sNGI: Serotonin-Norepinefrin Gerialım İnhibitörü (venlafaksin, duloksetin), NEGI: Norepinefrin Gerialım Inhibitörü (atomoksetin), AA: AtipikAntipsikotikler (risperidon, aripipirazol, ketiapin),

NaSSA: Noradrenerjik ve Spesifik Serotonerjik Antidepresan (mirtazapin), t:n(\%)

ki-kare testi: $\chi 2(1)=30.136, p<0.001$, Tablo I). Yine depresyon șiddetine göre ayrımış gruplar ile aile öyküsü arasındaki ilișki incelendiğinde gruplar arasında istatistiksel açıdan anlamlı düzeyde fark olduğu (ağır şiddetli MDB grubunda ailede psikiyatrik bozukluk \%44, Pearson $\chi^{2}(2)=6.780, p=0.034$ ) bulunmuştur (tabloda gösterilmedi).

Örneklem özkııım girişimi açısından değerlendirildiğinde tamamlanmamış özkıyım girişimi varlı̆̆ tüm ergenlerin \%10'unda $(n=35)$ saptanmış olup tümünün (\%100) ağır depresif grupta yer aldığı $(n=35)$ gözlenmişstir (Pearson $\chi 2(2)=350.000, p<0.001$ )

MDB'ye eșlik eden psikiyatrik eş tanılar açısından örneklem değerlendirildiğinde ergenlerin \%54'ünde $(n=189)$ en az bir psikiyatrik eș tanı varıı̆ı saptanmış olup bu oran istatistiksel olarak anlamlı bulunmamıștır (Non-parametrik-tek grup-ki-kare testi: $\chi 2(1)=2.240, p=0.134$, Tablo I). Depresyon şiddetine göre ayrımış gruplar ile eş tanı varlığı arasında da anlamlı bir ilişki saptanmamıştır (Pearson $\chi 2(2)=4.912, p=0.086$, tabloda gösterilmedi).

Tablo III: llaç yan etkileri.

\begin{tabular}{|l|c|c|}
\hline & $\mathbf{n}$ & $\%$ \\
\hline Yok & 320 & 91.4 \\
\hline En az bir yan etki varı̆ı̆ı & 30 & 8.6 \\
\hline Mide bulantısı & 6 & 1.7 \\
\hline Uykululuk & 6 & 1.7 \\
\hline Kilo artışı & 5 & 1.4 \\
\hline Uykusuzluk & 3 & 0.9 \\
\hline Ellerde titreme & 2 & 0.6 \\
\hline Unutkanlık & 1 & 0.3 \\
\hline İştahsızlık & 1 & 0.3 \\
\hline
\end{tabular}

Örneklemde saptanan en sık eș tanının anksiyete bozuklukları olduğu (\%20, n=70), bunu karșı olma karșı gelme bozukluğu (KOKGB) ve davranım bozukluğu (DB) birlikteliğinin (\%12, $\mathrm{n}=42$ ) ve dikkat eksikliği hiperaktivite bozukluğu (DEHB)'nun (\%7.1, n=25) takip ettiği görülmüştür. Bu durum eş tanıların varlığının depresyonun şiddetinden bağımsız olduğu şeklinde yorumlanmıştır. Tüm veriler Tablo l'de gösterilmiştir.

Uygulanan tedavi seçenekleri açısından örneklem incelendiğinde örneklemin \%81.7'sinin ( $\mathrm{n}=286)$ farmakolojik tedavi aldığı ve bu durumun anlamlı olduğu $(\chi 2(4)=27.936, p<0.001)$, \%15.1'inin $(n=53)$ yalnızca psikoterapi desteği aldığı \%3.1'inin ise $(n=11)$ farmakoterapi ve BDT kombinasyonu aldığı saptanmıștır (Tablo II).

Farmakoterapi seçeneklerine bakıldığında tüm ergenlerin \%87.4'ünde ( $\mathrm{n}=306)$ seçici serotonin gerialım inhibitörlerinin (SSGi) tek başına ve en sık olarak tercih edilmiş olduğu (Pearson $\chi 2(16)=33.746, p<0.001$ ), etken madde dağılımlarına göre bakıldığında en sık sertalin (\%56.3, $n=197)$ ve fluoksetin (\%14.3, $n=50$ ) kullanııldı̆̆ı saptanmıştır. Ergenlerin \%6'sında ise $(n=21)$ bir SSGi ile bir atipik antipsikotik ilacın birlikte kullanıldığı görülmüştür (Tablo II).

Farmakoterapi uygulanan ergenler ilaç yan etkisi açısından incelendiğinde, \%91.4'ünde $(n=320)$ bildirilen herhangi bir yan etki saptanmazken \%8.6'sında $(n=30)$ en az bir yan etki varlığı saptanmışıı (Tablo III).

Tedavi seçeneklerine göre yapılan analizlere bakıldığında, tamamlanmamış özkıyım girişimi ile tedavi için seçilen yöntem arasında (Pearson $\chi 2(2)=5.144, p=0.076)$ ve eș tanı varlı̆̆ı ile uygulanan tedavi arasında $(\chi 2(2)=2.211, p=0.331)$ anlamlı bir fark saptanmamıştır. Bununla birlikte yas reaksiyonu varlığında farmakoterapi ve BDT kombinasyonu tercihinin anlamlı olduğu (Pearson $\chi 2(2)=17.922, p=0.001)$, benzer durumunsomatoform bozukluk (disosiyatif ve konversif bozukluk) varlığında da geçerli 
Tablo IV:Tedavi seçeneklerine göre demografik ve klinik özelliklerin karşılaştırması.

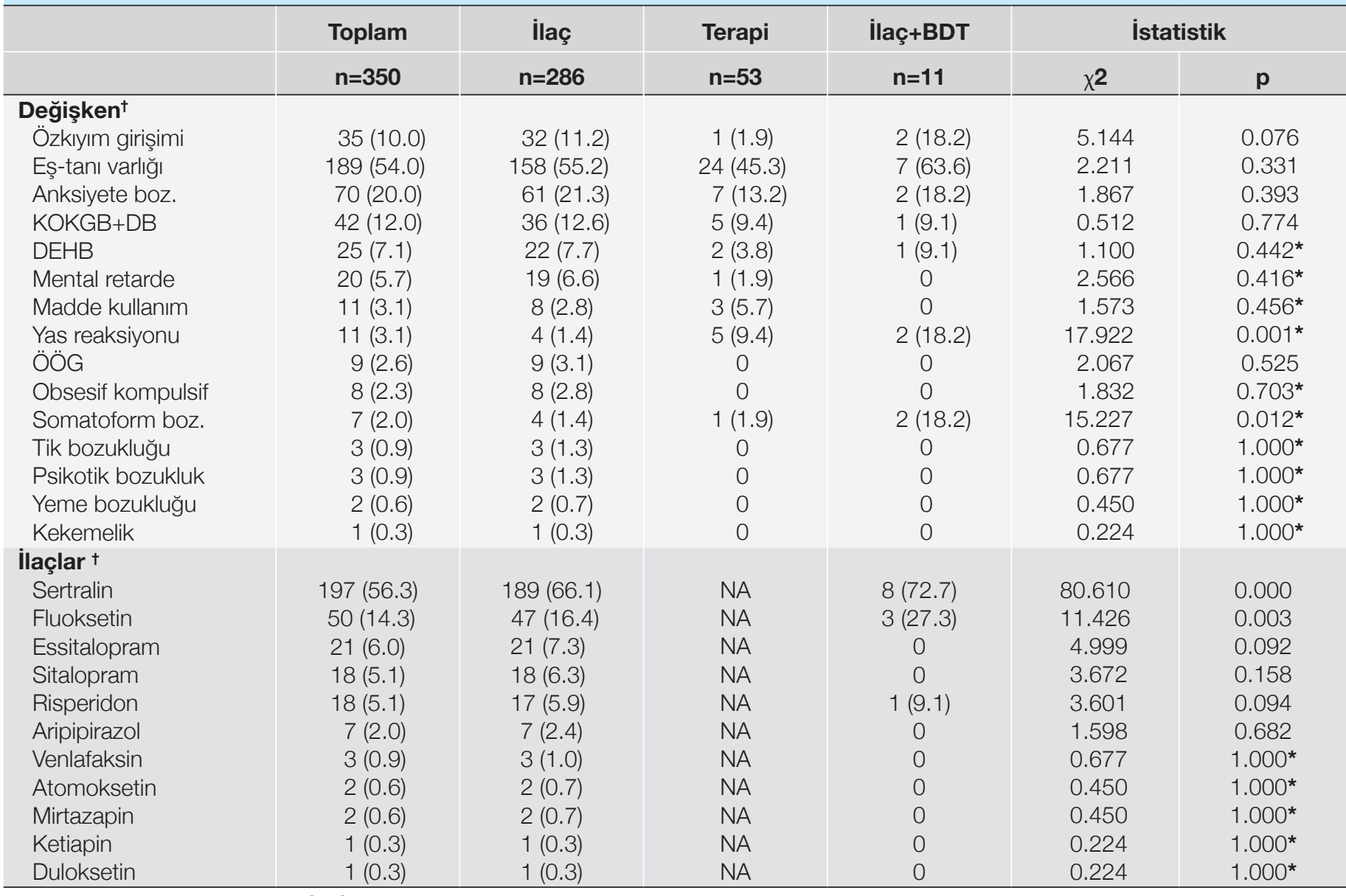

BDT: Bilişsel Davranış̧ı Terapi, KOKGB: Karşı olma karşı gelme bozukluğu, DB: Davranım Bozukluğu, DEHB: Dikkat eksikliği hiperaktivite bozukluğu, ÖÖG: Özgül öğrenme güçlüğü, NA: Not-applicable, ${ }^{t}: n(\%)$

Tablo V: Cinsiyete göre demografik ve klinik özelliklerin karşılaştırması.

\begin{tabular}{|c|c|c|c|c|c|}
\hline & \multirow{2}{*}{$\begin{array}{c}\text { Toplam } \\
\mathrm{n}=\mathbf{3 5 0} \\
\end{array}$} & \multirow{2}{*}{$\begin{array}{c}\mathrm{K} / \mathrm{z} \\
\mathrm{n}=264\end{array}$} & \multirow{2}{*}{$\begin{array}{c}\text { Erkek } \\
\mathrm{n}=86\end{array}$} & \multicolumn{2}{|c|}{ İstatistik } \\
\hline & & & & t ya da $\chi^{2}$ & $\mathbf{p}$ \\
\hline Yaş (yıl)a & $15.9(1.5)$ & $15.8(1.5)$ & $16.1(1.6)$ & 1.606 & 0.109 \\
\hline Özkıyım girişimi* & 35 (10.0) & $33(12.5)$ & $2(2.3)$ & 7.461 & 0.006 \\
\hline Eş-tanı varlığı* & 189 (54.0) & $133(50.4)$ & $56(65.1)$ & 5.672 & 0.017 \\
\hline
\end{tabular}

a: Ortalama (Standart sapma), *: n(\%)

olduğu (Pearson $\chi 2(2)=15.227, p=0.012)$ saptanmıștır. Diğer komorbid durumlarda ise tedavi seçeneklerinin benzer oranlarda uygulandığı gözlenmiştir (Tablo IV).

Cinsiyet değişkenine göre analiz yapıldığında, yaş değişkeni açısından kız ve erkek ergenlerin birbirine benzer oranlarda olduğu saptanmıştır (t(348)=1.606, $p=0.109)$. Özkıyım girişiminin kIz ergenlerde (Pearson $\chi 2(1)=7.461, p=0.006$ ), eş tanı varlığının erkek ergenlerde (Pearson $\chi 2(1)=5.672, p=0.017$ ) anlamlı düzeyde yüksek olduğu saptanmıştır (Tablo V). Diğer tüm değişkenlerin (okula devam, birinci derece yakında depresyon, tedavi seçenekleri, ilaç yan etki dağılımı vb) birbirine benzer oldukları saptanmıştır (tümü için p>0.05, tabloda gösterilmedi).

\section{TARTIŞMA}

MDB ataklarla giden veya kronik seyir gösterebilen bir psikiyatrik bozukluktur. MDB tanılı bireylerde işlevsellik alanlarında bozulma belirgindir (2). Klinik görünüm yaș, cinsiyet, eğitim durumu ve kültürel özelliklere göre değişebilir. Çoğu erişkin MDB olgusunda hastalık öyküsü ergenlik dönemine kadar uzanmaktadır. Bu nedenle ergenlik döneminde MDB özelliklerini anlamak, tanı koymak ve tedavi etmek önemlidir.

Alan yazında çocuk ve ergen yaş grubunda MDB şiddetinin değerlendirildiği çalışmalar son derece sınırlıdır. ABD'de MDB tanılı ergenler arasında yapılan bir çalışmada ergenlerin \%25 
inden fazlasının şiddetli MDB ölçütlerini (yüksek düzeylerde sıkıntı ve bozulma ile karakterize) karşıladığı bildirilmiştir (14).

Ülkemizde ilkokul öğrencileri arasında yapılan bir çalışmada \%30 oranında orta, \%6 oranında ağır depresif belirti saptanmıştır (22). Erişkin kadın örneklemde Hamilton Depresyon Derecelendirme Ölçeği (HDDÖ) kullanılarak yapılan bir çalışmada ise, olguların \%25'inin hafif, \%20.4'ünün orta, \%22.7'sinin ağır düzeyde depresyonu olduğu bulunmuştur (23). Çalışmamızda ise örneklemin \%10'unun ( $n=35)$ ağır şiddetli depresyon grubunda yer aldığı bulunmuştur. Major depresyonu olan ergenlerde, üzerinde önemle durulması gereken bir komplikasyon intihar girişimleridir. Çünkü ergenlerde erişkinlere göre hem ölümle sonuçlanan olgu sayısı daha fazladır hem de MDB'de görülen artışla ilişkili olarak, intihar oranları da giderek artmaktadır. Çalışmamızda tamamlanmamış özkıyım girişimi öyküsü varlığı örneklemin \%10'unda (n=35) saptanmış olup tümü (\%100) ağır depresif grupta yer almaktadır.

Klinik ve toplum bazlı çalışmalarda MDB tanılı çocuk ve ergenlerde \%40-70 oranlarında bir ya da daha fazla eş tanı görülebilmektedir (24). Eş tanı, Özellikle şiddetli depresyonu olan ergenlerde artmaktadır ve ciddi bozulma, kötü prognoz ve tedaviye direnci öngörmektedir (3). Tedaviye direnç ise, belirtilerde kötüleşme ve intihar riskinde artışı öngörmektedir. Alan yazında yapılmış bir çalışmada MDB tanısı alan çocuk ve ergenlerin \%89.6 sında en az bir eș tanı, \%63.8'inde iki veya daha fazla eș tanı saptanmıştır (25) Ülkemizde yapılan başka bir çalışmada MDB tanılı çocuk ve ergenlerde \%64.6 oranında eş tanı varlığı bildirilmiştir (26). Çalışmamızda MDB'ye eșlik eden psikiyatrik eş-tanılar açısından örneklem değerlendirildiğinde ergenlerin \%54'ünde ( $n=189)$ en az bir psikiyatrik eș tanı varlığı saptanmıştır. Depresyon şiddetine göre ayrılmış gruplar ile eş tanı varlığı arasında anlamlı bir ilişki saptanmamıştır. Her ne kadar geriye dönük bir çalışma ile neden-sonuç ilişkisi kurmak mümkün olmasa da bu durum var olan eş tanıların depresyon etiyolojisinden başka nedenlerle ortaya çıkmış olabileceğini düşündürmektedir. Özellikle depresyonla çok sık görülen anksiyete belirtilerinin depresyon şiddeti ile ilişkili çıkmaması psikoterapi yöntemi ve ilaç tedavisi seçimi açısından klinisyenler için akılda tutulması gereken bir sonuç gibi görünmektedir.

Ergenlerde MDB'ye eșlik eden eș tanılar arasında en sık anksiyete bozuklukları, davranım bozuklukları, DEHB, obsesif kompulsif bozukluk ve öğrenme bozuklukları olarak belirlenmiştir. (27). Epidemiyolojik bir çalışmada MDB tanısı alan çocuk ve ergenlerin tanıyı takip eden 3 aylık sürede, \%28'inin anksiyete bozukluğu, \%7'sinin DEHB, \%3'ünün karşı olma karşı gelme bozukluğu (KOKGB), \%3'ünün davranım bozukluğu (DB), \%1'inin ise madde kullanım bozukluğu eş tanılarını aldığı gösterilmiştir (28). Çalışmamızda MDB' ye en sık eşlik eden tanının anksiyete bozuklukları olduğu ( $n=70, \% 20)$, bunu KOKGB ve DB ile DEHB'nin takip ettiği görülmüştür. Ergenlik döneminde MDB'de eș tanının sık görülmesinin hem ortak risk faktörleri ile ilişkili olabileceği hem de bu eș tanılara sahip ergenlerin çevreden aldığı eleştirel geri bildirimler, akademik ve sosyal işlevsellikte bozulmanın getirdiği özgüven eksikliği ve yalnızlığın depresyon gelişimine katkıda bulunuyor olabileceği düşünülmüştür. Daha önceki çalışmalar eş tanıların depresyonun yineleme riskini, depresif nöbetin süresini, intihar girişimi veya intihara yönelik davranışlarda bulunmayı, işlevsel durumu, tedaviye yanıtı ve psikiyatri servislerinin kullanımını olumsuz etkilediğini de ortaya koymaktadır $(19,29)$. Bu veriler ışığında eș tanıların depresyon şiddetini etkilemese de hastalık seyrini kötü yönde etkilediği ve tedaviye tam yanıtı azalttığı söylenebilir

Çalışmamızın sonuçlarını cinsiyet açısından ele alacak olursak, bir yıllık süre içerisinde kliniğimize başvuran MDB tanılı ergenlerden oluşan örneklemde, kız ergenlerde erkeklere göre 3 kat daha fazla olduğu saptanmıştır. Özyurt ve Baykara (27) gözden geçirme yazılarında MDB'nin ergenlik öncesi dönemde kız ve erkek cinsiyette eșit oranda görülürken ergenliğin bașından itibaren kızlarda erkeklerden daha fazla görüldüğünü belirtmişlerdir. Çalışma verilerimizle de desteklenen bu farklılı̆a, ergenlik döneminde cinsiyete özgü gelişen farklı nörobiyolojik değişiklikler yol açıyor olabilir. Cinsiyet farklıı̆ını açıklamak için nörohormonal farklılıklar, genetik etkenler, cinsiyete bağlı sosyalizasyon farklılıkları gibi çeşitli varsayımlar ortaya atılmıştır (30). Pubertal durumun (hangi puberte evresinde olduğu), pubertal zamanlamanın (hangi yaşta pubertal değişimlerin başladığı), yaş ve hormonlardaki değişimlerin kız ergenleri olumsuz yaşam olayları ile baş edebilme konusunda duyarlı hale getirdiği ileri sürülmektedir (23). Cyranowski ve ark.(31) ise bu prevelans farklılığının sebebinin sadece pubertal hormonal değişimlere bağlı olmayıp bunun yanı sıra ebeveynlerle, akranlarla, romantik/cinsel ilişkilerdeki majör değişiklikleri içeren sosyal rollerdeki farklılıklarında rolü olduğunu ileri sürmüşlerdir .

MDB etiyolojisi multifaktöriyeldir ve ergenlerde depresyon etiyolojisinde ailesel ve genetik risk, biyolojik incinebilirlik, psikososyal risk faktörleri ve gen-çevre etkileşimi önemli rol oynamaktadır (3). Ebeveyn depresyonu; çalışmalarda en fazla işaret edilen etiyolojik etkendir (27). Çalışmamızda da depresyon tanılı ergenlerin birinci derece yakınlarında en az bir psikiyatrik bozukluk varlığı tek başına anlamlı bulunmuştur. Ayrıca ailesel risk arttıkça depresyon şiddetinin de arttığı gözlenmiştir. Bu durum önceki çalışmalarla uyumludur. Özer ve ark. (18) ise depresyonu olan erişkinler, onların çocukları ve depresyonu olan ergenlerle çalışmış ve MDB çocuk ve ergenlerde aile ilişkilerinin normal kontrollere göre daha çatışmalı ve reddedici olduğu, iletişim problemlerinin daha fazla yaşandığı, duygunun daha az ifade edildiği ve destekleyici tutumların daha az olduğu gösterilmiştir (18). İlgili alanda yapılan bir gözden geçirme çalışmasında MDB öyküsü olan bir anne-babaya sahip olmanın çocuk ve ergen depresyonu için en güçlü tetikleyicilerden biri olduğu bildirilmiştir (29).

MDB'nin şiddetine göre tedavi yaklaşımları farklılık göstermektedir. Hafif olgularda öncelikle psikoeğitim ve destekleyici tedavi uygulanırken orta ve ağır şiddetli MDB olgularında farmakoterapi, BDT, KAT gibi tedavi yöntemleri uygulanmaktadır (32). Çalışmamızda örneklemin tamamına 
destekleyici tedavi ve psikoeğitim verilmiş ve büyük çoğunluğuna farmakolojik tedavi eklenmiștir. Çocuk ve ergenlerde MDB'nin farmakolojik tedavisinde SSGi kullanımı illk seçenektir (32). Cocuk ve ergen MDB tanılı hastaların kısa süreli tedavisinde SSGi'lerin etkinliği ve güvenilirliği, plasebo kontrollü fluoksetin, sertralin ve sitalopram çalıșmalarında gösterilmiștir (33-36). MDB tanılı ergenlerde yapılımıs bir tedavi çalıșmasında ise (Treatment of Adolescent with Depression-TADS çalıșması) fluoksetin, hem monoterapi olarak hem de BDT ile kombine olarak plasebodan üstün bulunmuștur (37). Çalıșmamızda tüm olguların \%87.4'ünde SSGi tek bașina tercih edilmiș ve en sık sertalin kullanıldı̆̆ı saptanmıștır. Fluoksetin ve sertralin tercihinin istatistiksel olarak anlamlı olduğu tespit edilmiștir. Yetișkinlerin aksine, trisiklik antidepresanlar (TCA) MDB tanilı ergenlerde etkin seçenek değildir (3). MDB'nin etiyolojisinde tanımlanmış olan serotonin hipotezine göre MDB'ye artmış yatkınlığın, serotonin salınımında ya da reseptörlerinde azalmaya bağlı olduğu düșünülmüş, depresyondaki hastaların bozulmuş beyin serotonin ișlevlerinin farmakolojik olarak düzeltilmesinin depresyonun düzeltilmesinde yeterli olacağı belirtilmiștir (38). SSGi'lerin depresyon tedavisinde etkin bir biçimde kullanillyor olması serotoninin MDB'deki rolünü destekler niteliktedir. Sertralinin, sinaptik aralıkta dopamin taşıyıcı proteinini (DAT) inhibe ederek 'atipik depresyonu' olan bazı hastalardaki așır uyuma, düșük enerji ve tepkisellik belirtilerini düzelten ılımlı ve istenen canlandıııcı etkileri gözlemlenmiștir (39). Kliniğimizde, ergen yaș grubunda atipik depresyon belittilerinin daha sıklıkla görülmesi nedeni ile sertralin öncelikle tercih edilmiștir. SSGi'ler günümüzde tolerabiliteleri ve emniyetleri açısından her yaș grubunda ve genel tıbbi bir hastalığı olan bireylerde MDB tedavisi için tercih edilebilmektedir. SSGi'lerin yan etkilerinin sıklığı, çeșitliliği ve ciddiyeti diğer antidepresan gruplarına göre daha azdır. Yan etkiler çoğunlukla tedavinin bașında ortaya çıkmakta zamanla azalmaktadır (32). En yaygın görülen yan etkiler gastrointestinal semptomlar, uyku değişiklikleri (uykusuzluk veya uyuklama, canlı düşler, kabuslar), huzursuzluk, terleme, baș ağrısı, akatizi, iștah değișiklikleri (artıș veya azalma) ve cinsel ișlev bozukluğudur (17). Gençlerin, özellikle de çocukların yaklașık \%3-8'inde dürtüsellik, ajitasyon, sinirlilik, sersemlik ve davranışsal aktivasyon artıșı da görülebildiği bildirilmektedir (17). Çalıșma verilerimiz ergen yaș grubunda antidepresan tedavi için yan etki olasilığının düşük olduğunu göstermiş olup olguların yalnızca \%8.6'sında en az bir yan etki varlığı saptanmıștır.

Bulgularımı değerlendirildiğinde literatürle uyumlu olarak MDB'nin tüm şiddet gruplarında kızlarda daha fazla olduğu, sıklikla tedaviye farmakoterapinin eklendiği ve SSGi grubu ilaçların ilk ve en sık tercih edilen ilaç grubu olduğu saptanmıștır. Çalıșmamızda MDB tanıı ergenlerde yüksek oranlarda eș tanı varı̆̆ı saptanmıștır. Eș tanı varlığı tedaviyi ve tedaviye uyumu güçleștirmesi, hastanın prognozunu ve yașam kalitesini olumsuz etkilemesi açısından göz önünde tutulması gereken oldukça önemli bir konudur. Bu alanda çalışan klinisyenlerin tanı koyma ve tedavi sürecinde bu duruma dikkat etmesi doğru ve etkili bir tedavi uygulanması açısından yararlı olacaktır.
Sonuç olarak çalışmamızın MDB tanısı konan ergenlerde yapılmış geniş örneklemli, şiddet ve tedavi değerlendirmesini içeren bir çalışma olması açısından alan yazına katkı sağlayacağı düşünülmüştür;

Her ne kadar bu veriler kesitsel, geriye dönük ve durum saptaması niteliğinde olup genellenebilir olmasa da özellikle kız ergenlerin hastalık açısından ciddi risk altında olduğu, komorbiditelerin depresyon şiddeti ile ilişkisi, klinik pratikte göz önünde bulundurulmalıdır.

\section{KAYNAKLAR}

1. American Psychiatry Association (APA), Diagnostic and statistical manual of mental disorders (DSM-5). American Psychiatric Publication, 2013.

2. Rey JM, Bella-Awusah TT, Liu J. Chapter E. Depression in children and adolescents. In IACAPAP Textbook of Child and Adolescent Mental Health. 2015.

3. Thapar A, Collishaw S, Pine DS, Thapar AK. Depression in adolescence. The Lancet 2012; 379:1056-67.

4. Ebert MH, Loosen PT, Nurcombe B. Current Diagnosis \&Treatment Psychiatry. Candansayar S (Çeviri Ed.), 1. Baskı: 2003.

5. Hauenstein EJ. Depression in adolescence. J Obstet Gynecol Neonatal Nurs 2003; 32: 239-48.

6. Meadows SO, Brown JS, Elder GHJ. Depressive symptoms, stress, and support: gendered trajectories from adolescence to young adulthood. Journal of Youth and Adolescence 2006;35:8999.

7. Burns JJ, Cottrell L, Perkins K, Pack R, Stanton B, Hobbs G, et al. Depressive symptoms and health risk among rural adolescents. Pediatrics 2004;113:1313-20.

8. Eskin M, Ertekin K, Harlak H, Dereboy Ç. Lise öğrencisi ergenlerde depresyonun Yaygınlığı ve İlişkili Olduğu Etmenler. Türk Psikiyatri Dergisi 2008:19:382-9.

9. Sims BE, Nottelmann E, Koretz D, Pearson J. Prevention of depression in children and adolescents. Am J Prev Med 2007; 32:451-5

10. Coghill D, Usala T. Mood disorders in children and adolescents. Psychiatry 2006; 5:123-7.

11. Birmaher B, Brent D, AACAP Work Group on Quality Issues, Bernet $\mathrm{W}$, Bukstein $\mathrm{O}$, Walter $\mathrm{H}$, et al. Practice Parameter for the ssessment and Treatment of Children and Adolescents With Depressive Disorders. J Am Acad Child Adolesc Psychiatry 2007;46:1503-26.

12. Ağaoğlu B. Major Depresif Bozukluk Çocuk ve Ergen Ruh Sağlığ ve Hastalıkları. Aysev A, Taner Y. Asimetrik Paralel Yayınevi. İstanbul 2007.

13. Birmaher B, Arbelaez C, Brent D. Course and outcome of child and adolescent major depressive disorder. Child Adolesc Psychiatr Clin N Am 2002;11:619-37.

14. Avenevoli S, Swendsen J, He J-P, Burslein M, Merikangas KR. Major depression in the National Comorbidity Survey-Adolescent Supplement: prevalence, correlates, and treatment. J Am Acad Child Adolesc Psychiatry 2015;54:37-44.

15. Birmaher B, Brent DA, Benson RS. Summary of the practice parameters for the assessment and treatment of children and adolescents with depressive disorders. J Am Acad Child Adolesc Psychiatry 1998;37:1234-8. 
16. Graham J. Emslie, Taryn L. Mayes. Depression in Children and Adolescents Guide to Diagnosis and Treatment CNS Drugs 1999;11:181-9.

17. Birmaher B, Brent D, AACAP Work Group on Quality Issues. Practice parameter for the assessment and treatment of children and adolescents with depressive disorders. J Am Acad Child Adolesc Psychiatry 2007: 46:1503-26.

18. Özer D, Kocabıyık A, Girgin V, Demiraslan P. Ergenlerde Depresyon: Epidemiyoloji, Klinik Görünüm, Komorbidite, Seyir, Komplikasyonlar. Düșünen Adam: The Journal of Psychiatry and Neurological Sciences 2002;15:90-6.

19. Tamar M, Özbaran B. Çocuk ve ergenlerde depresyon. Klinik Psikiyatri 2004;2:84-92.

20. Maughan B, Collishaw S, Stringaris A. Depression in childhood and adolescence. J Can Acad Child Adolesc Psychiatry 2013;22:3540.

21. Davidson JR, Meltzer-Brody SE. The underrecognition and undertreatment of depression: what is the breadth and depth of the problem? J Clin Psychiatry 1999;60 Suppl 7:4-9.

22. Öy B. Çocuklar İçin Depresyon Ölçeği. Geçerlilik Güvenilirlik Çalışması. Türk Psikiyatri Dergisi 1991;2:132-6.

23. Akdeniz F, Gönül AS. Kadınlarda üreme olayları ile depresyon ilişkisi. Klinik Psikiyatri 2004;2:70-4.

24. Essau CA. Comorbidity of depressive disorders among adolescents in community and clinical settings. Psychiatry Res 2008;158:3542.

25. Fu-i L, Wang YP. Comparison of demographic and clinical characteristics between children and adolescents with major depressive disorder Braz J Psychiatry 2008; 30:124-31.

26. Yıldırım V, Toros F, Sungur MA, Yılmaz MF. Majör Depresif Bozukluğu Olan Çocuk ve Ergenlerin Sosyodemografik Değişkenleri ve Risk Etmenleri. Literatür Sempozyum 2015;1:8-16.

27. Özyurt G, Baykara B. Ergenlerde Depresyon Tanısı, Ayırıcı Tanısı,Kliniği. Turkiye Klinikleri Journal of Child Psychiatry-Special Topics 2016; 2:50-4

28. Costello EJ, Mustillo S, Erkanli A.Prevalence and development of psychiatric disorders in childhood and adolescence. Arch Gen Psychiatry 2003; 60:837-44.
29. Bodur Ș, Üneri Ö. Çocuk ve ergenlerde majör depresif bozukluk: Bir gözden geçirme. Anadolu Psikiyatri Dergisi 2008; 9:105-10

30. Kessler RC, Avenevoli S, Merikangas KR. Mood disorders in children and adolescents: an epidemiologic perspective. Biol Psychiatry 2001;49:1002-14.

31. Cyranowski JM, Frank E, Young E. Adolescent onset of the gender difference in lifetime rates of major depression: a theoretical model. Arc of Gen Psychiatry 2000;57:21-7.

32. Koç EB, Karaçetin G. Çocuk ve Ergenlerde Depresif Bozukluk Farmakolojik Tedavisi. Türkiye Klinikleri Çocuk Psikiyatrisi Özel Dergisi 2016; 2:55-61.

33. Emslie GJ, Rush AJ, Weinberg WA, Kowatch RA, Hughes CW, Carmody T, et al. A double-blind, randomized, placebo-controlled trial of fluoxetine in children and adolescents with depression. Arch Gen Psychiatry 1997;54: 1031-7.

34. Emslie GJ, Heiligenstein JH, Wagner KD, Hoog SI, Ernest DE, Brown E, et al. Fluoxetine for acute treatment of depression in children and adolescents: a placebo-controlled, randomized clinical trial. J Am Acad Child Adolesc Psychiatry 2002;41:120515.

35. Wagner KD, Ambrosini P, Rynn M, Wohlberg C, Yang R, Greenbaum MS, et al. Efficacy of sertraline in the treatment of children and adolescents with major depressive disorder: two randomized controlled trials. JAMA 2003; 290:1033-41.

36. Wagner KD, Robb AS, Findling RL, Jin J, Gutierrez MM, Heydorn WE. A randomized, placebo-controlled trial of citalopram for the treatment of major depression in children and adolescents.Am J Psychiatry 2004;161:1079-83.

37. March J, Silva S, Petrycki S, Curry J, Wells K, Fairbank J, et al. Fluoxetine, cognitive-behavioral therapy, and their combination for adolescents with depression: Treatment for Adolescents With Depression Study (TADS) randomized controlled trial. JAMA 2004; 292: 807-20.

38. Baldwin D, Rudge S. The role of serotonin in depression and anxiety. Int Clin Psychopharmacol 1995;9:41-6.

39. Stahl S. Stahl's Essential Psychopharmacology: Neuroscientific Basis and Practical Applications. First ed ed. İstanbul: İstanbul Tıp Kitabevi 2015;296-300. 